ISSN:1991-8178
EISSN: $2309-8414$
DOI: $10.22587 /$ ajbas.2017.11.14.1
Journal home page: www.ajbasweb.com

\title{
Quality Indicators of The Forest Harvesting Process In Clear-Cut Operations of Eucalyptus Stands For Energetic Purposes
}

\author{
${ }^{1}$ Jean Alberto Sampietro, ${ }^{2}$ Marcelo Bonazza, ${ }^{1}$ Philipe Ricardo Casemiro Soares, ${ }^{3}$ Julio Peretti da Silva, ${ }^{4}$ Julio Eduardo Arce, \\ ${ }^{4}$ Jaime Wojciechowski, ${ }^{4}$ Renato Cesar Gonçalves Robert \\ ${ }^{1}$ Professor, Department of Forestry Engineering, State University of Santa Catarina (UDESC),Lages, SC, ZIP code: 88520-000, Brazil. \\ ${ }^{2}$ Professor, Department of Agriculture,Biodiversity and Forests, Federal University of Santa Catarina, Curitibanos,SC, ZIP code: 89520- \\ OOO, Brazil. \\ ${ }^{3}$ Msc. Student, Forestry Engineering Department,State University of Santa Catarina (UDESC), Lages, SC, ZIP code: 88520-000, Brazil. \\ ${ }^{4}$ Professor, Department of Forest Science, Federal University of Paraná (UFPR), Curitiba, PR, ZIP code: 80210-170, Brazil.
}

\section{Address For Correspondence:}

Jean Alberto Sampietro, State University Santa Catarina (UDESC), Department of Forestry Engineering, AvenidaLuiz de Camões, 2090, Bairro Conta Dinheiro, Lages, SC, Brazil. ZIP code: 88520-000.

E-mail: jean.sampietro@udesc.br

\section{ART I CLE INFO}

\section{Article history:}

Received 12 October 2017

Accepted 22 November 2017

Available online 6 December 2017

Keywords:

Forest operations; Statistical Process

Control; Quality management.

\begin{abstract}
A B S T RA C T
Background: Some organizations in the Brazilian forestry industry do not follow the development pace ofother industries, in order toadopttools and quality management methodologies. Asresult, the low quality and high instability of processes create a lot of waste in the sector. Thisis intensified in forest harvesting operations because this is one of the activities that most contributesto the production costs of a forestry business. Objective: Evaluatequality indicators in activities of tree felling, tree bucking in the field and log cutting at the company yard to subsidize future improvements that may increase the quality and profitability of the forest harvesting process. Results: The tree felling and log cutting at the company yard activities are in nonconformity, exceeding the lower and upper limits of statistical process control. Whilst, the trees bucking in the field can be considered a statistically stable process, being in accordance with the specifications of the company. Conclusion: In general, adjustments can be made to improve the quality of the analyzed operations and increase revenues by avoiding losses of wood in the forest harvesting process. The methodology of Statistical Process Control has proved to be an important tool for the quality management of forest operations.
\end{abstract}

\section{INTRODUCTION}

The concern with quality indicators is not a recent fact. When products used to be handcrafted, there was a direct contact between the artisan and his customers, which made it possible to control the quality of purchased products. Thus, from a corrective approach, there was the inspection of the entire production. With the industrial revolution, there was a need to increase production to meet the demand of the population, which was also growing. This fact has resulted in the creation of industries with the focus on the quantity produced. Then problems with the quality of the products acquired started to worry the consumers (Trindade et al., 2012).

Over time, customers have become more demanding, which prompted companies to strive for excellence in the quality of their products. For this, organizations operating in different sectors of the economy have adopted preventive approaches by applying quality characteristics to their production processes and, consequently, preventing product failures from reaching customers.

As follows, the search for tools that facilitate the identification of nonconformities and allow decisionmaking in a timely manner was intensified. However, in the Brazilian forestry sector, some organizations have

Open Access Journal

Published BY AENSI Publication

(C) 2017 AENSI Publisher All rights reserved

This work is licensed under the Creative Commons Attribution International License (CC BY).

http://creativecommons.org/licenses/by/4.0/

\section{(c) (i) Open Access}

To Cite This Article: Jean Alberto Sampietro, Marcelo Bonazza, Philipe Ricardo Casemiro Soares, Julio Peretti da Silva, Julio Eduardo Arce, Jaime Wojciechowski, Renato Cesar Gonçalves Robert., Quality Indicators of The Forest Harvesting Process In Clear-Cut Operations of Eucalyptus Stands For Energetic Purposes. Aust. J. Basic \& Appl. Sci., 11(14): 1-8, 2017 
uncertain survival due to not keeping pace with the development and adoption of quality management tools and methodologies(Trindade et al., 2007; Martins, 2017).

Thus, to ensure survival, it is necessary for the Brazilian forestry sector to create a "quality culture", adopting verification procedures and quality monitoring in its activities to raise its competitiveness in the international market. Nevertheless, the concern should not only be with the final product obtained, but with each stage of production, in order to reduce costs, guaranteeing the quality of the whole process, obtaining a final product of high quality and at cost competitive(Rezende et al., 2000).

Although Brazil is globally recognized for the high productivity of its forests (IndústriaBrasileira de Árvores, 2017), the low quality scenario is due to the lack of investment, as well as the lack of research that proves the feasibility of adopting quality tools forest production activities. Nevertheless, it is important to highlight the difficulties in adapting the methodologies of the quality tools to the specificities of the wholesilvicultural process, compared to the studies carried out in wood processing or in other sectors of the economy.

Thus, among the stages of forest production, harvesting and transportation have great importance, given the risks of losses involved in these activities and the high cost of this operation, which may represent more than $50 \%$ of the price of wood that comes to industry (Siqueira et al., 2004; Machado et al. 2014). Therefore, the implementation of quality programs in this area possibly brings bigger and faster returns comparing to the other segments of the forestry productive chain (Jacovine and Trindade, 2014).

In this context, the objective of this study was to evaluate the quality of tree felling operations, tree bucking in the field and log cutting at the company yard. This evaluation was in order to infer if the process is operating within specified limits in the company and, therefore, can subsidize future improvements that may increase the quality and profitability of the activity.

\section{MATERIAL AND METHODS}

\section{Characterization of the study area:}

The study took place in areas of a forest company located in the city of Rio Negrinho, which is located in the Northern Plateau Region of Santa Catarina in Brazil. Moreover, the city is located at an average altitude of 791 meters above sea level, ranging between 800 and 1050 meters. According to the classification of Köppen, the climate of the region is $\mathrm{Cfb}$. This indicates a tempered and constantly humid climate, without a dry season and with a fresh summer. The average annual temperature varies between 15 and $17{ }^{\circ} \mathrm{C}$, with average maximum temperatures ranging from 26 to $24^{\circ} \mathrm{C}$ and minimum of 10 to $11^{\circ} \mathrm{C}$ (Alvares et al., 2013). The mean annual rainfall is $1720 \mathrm{~mm}$, with relative air humidity ranging from 80 to $86 \%$ (Epagri, 2009).

In the areas, Eucalyptus ssp. plantations were cultivated with planting spacing of $3 \times 1.80 \mathrm{~m}$ and an average density of 1500 tree $^{-1}$. At the age of 14 years old, end of the rotation cycle, the plantations had an average height of $26.0 \mathrm{~m}$, mean of diameter at breast-height of $23.0 \mathrm{~cm}$ and mean of the volume per tree of $0.308 \mathrm{~m}^{3}$ tree ${ }^{1}$. The final goal of the production of wood was for energy purposes or, in other words, for logs to feed boilers in an industrial process. In general, we can characterize the relief of the cultivated areas as being from plain to wavy.

\section{Characterization of the evaluated harvesting system:}

The harvesting of the forest stands happened under clear-cut regime. Full Tree harvesting systemwas employed,with all the harvesting steps on the field and in the company yard performed with machines.

First, on the field, aTimberjack Feller Buncher 608 S,cut the trees and then theywere left there for around 180 days. After that, the trees were dragged from the core to the edge of the field using a Valtra Tractor BM 100with a winch (technical specifications in Table 1). Later, the felled trees were bucked into $\operatorname{logs}$ of $2.20 \mathrm{~m}$ length and then stacked and loaded in transport vehicles by two alternatives of machines: (1) Timberjack Grapple Saw 608Scoupled to a Dinamaccutting deviceDC600(technical specifications in Table 2); or (2) ValtraGrapple SawTractor BM 125i coupled to a Dinamaccutting device DC250 (technical specifications in Table 3).

After the operations on the field, the wood was transportedto an intermediate yard of the company where its unloading took place. A final processing into logs of $1.10 \mathrm{~m}$ in length happened and using a Valtra Grapple Saw Tractor BM 125i, which loadedthe logs for the final transportation. Themachinehas same technical specifications as previously mentioned (Table 3 ). 
Table 1: Technical specifications of Valtra Tractor BM 100.

\begin{tabular}{ll} 
Table 1: Technical specifications of Valtra Tractor BM 100. & \\
\hline Specifications & Description \\
\hline Brand & Valtra \\
Model & BM 100 \\
Engine & AGCO POWER 420DS, 4 cylinders \\
Gross power & $104.6 \mathrm{hp}(77.2 \mathrm{~kW})$ \\
Fuel capacity & $142 \mathrm{~L}$ \\
Traction & 4 WD \\
Type of whell & Tires \\
Usage time & \pm 4 years \\
\hline
\end{tabular}

Table 2: Technical specifications of Timberjack Grapple Saw 608S

\begin{tabular}{ll}
\hline Specifications & Description \\
\hline Base machine & Timberjack \\
\hline Brand & $608 \mathrm{~S}$ \\
Model & Cummins $6 \mathrm{CT} 8.3$ turbo, 6 cylinders \\
Engine & $205.2 \mathrm{hp}(153 \mathrm{~kW})$ \\
Gross power & $568 \mathrm{~L}$ \\
Fuel capacity & $1315 \mathrm{~kg}$ \\
Boom lifting capacity & $7.80 \mathrm{~m}$ \\
Maximum Boom Reach & Crawler tracks \\
Type of whell & \pm 10 years \\
Usage time & \\
\hline Cutting device & Dinamac \\
Brand & DC600 \\
Model & $0.600 \mathrm{~m}^{2}$ \\
Grapple opening area & \pm 2 years \\
Usage time & \\
\hline
\end{tabular}

Table 3: Technical specifications ofValtraGrapple Saw Tractor BM $125 \mathrm{i}$.

\begin{tabular}{ll}
\hline Specifications & Description \\
\hline Tractor & \\
\hline Brand & Valtra \\
Model & BM 125i \\
Engine & AGCO POWER 420DSA \\
Gross power & $130.2 \mathrm{hp}(96,7 \mathrm{~kW})$ \\
Traction & $4 \mathrm{x} 4$ \\
Type of whell & Tires \\
Maximum permissible weight & $7392 \mathrm{kgf}$ \\
Usage time & \pm 4 years \\
\hline Cutting device & \\
\hline Brand & Dinamac \\
Grapple opening area & $0.576 \mathrm{~m}^{2}$ \\
Usage time & \pm 2 years \\
\hline
\end{tabular}

\section{Quality Analysis:}

The quality of the processes of tree felling, tree bucking in the field and log cutting at the company yard

were evaluated by following variables: (1) stump height on the tree cutting stage; (2) precision on the bucking of the trees on the field; and (3) precision on the log cutting at the company yard.

In order to collect data of the height of stumps 10 sample plots with an area of $378 \mathrm{~m}^{2}(18 \times 21 \mathrm{~m})$ were set up.From the sample plots, measurements of diameters and heights of the stumps and the mean slope of each plot were taken. According to the company specification, $10 \mathrm{~cm}$ was considered as the desired height limit of the stumps. With this information, the volume of wood that remained in the field above the standard cutting height and the loss of revenue per hectare, assuming a market price of wood of US $\$ 19.25 \mathrm{per} \mathrm{m}^{3}$, were calculated.

For the analysis of the precision of bucking trees on the field and log cutting at the company yard, 17 and 10 samples composed of 15 and 10 replicates, respectively, were measured for each of the conditions. The standard compliance of the logs intended by the company was from 2.00 to $2.40 \mathrm{~m}$ for field cutting of trees and from 1.00 to $1.20 \mathrm{~m}$ for yard bucking.

Afterwards, with the data of the variables, the Statistical Process Control (SPC) analysis was performed. This analysis were done using control charts (mean and dispersion), according to the methodologies presented by Oakland (2003) and Montgomery (2004). For the control charts that considered the means of the processes the mean line (AL), the upper limit of control (UCL) and the lower limit of control (LCL) (Equations 1, 2 and 3)were obtained. Charts of dispersal control for standard deviation had their AL, LCL and UCL calculated based on Equations 4, 5 and 6, respectively. 
$A L=\frac{\sum x_{i}}{k}$

$U C L=\frac{\sum x_{i}}{k}+\left(A_{3} * \frac{\sum s_{i}}{k}\right)$

$L C L=\frac{\sum x_{i}}{k}-\left(A_{3} * \frac{\sum s_{i}}{k}\right)$

$A L=\frac{\sum s_{i}}{k}$

$U C L=B_{4} * \frac{\sum s_{i}}{k}$

$L C L=B_{3} * \frac{\sum s_{i}}{k}$

Where: $x_{i}$ is the mean value of each sample; $\mathrm{s}_{\mathrm{i}}$ : mean standard deviation of each sample; $\mathrm{k}$ : number of samples; $\mathrm{A}_{3}$ : constant used in the elaboration of control charts of the mean by the standard deviation; $\mathrm{B}_{3}$ and $\mathrm{B}_{4}$ : constants used in the elaboration of control charts of the mean by standard deviation.

\section{RESULTS AND DISCUSSION}

The mean height of the stumps ( \pm standard deviation) was $10.83 \mathrm{~cm}( \pm 6.18 \mathrm{~cm})$ (Figure 1), being out of the standard compliance according to the desired specificationand over the limits of the specifiedstatistical process control map (Figures 2A and 2B).

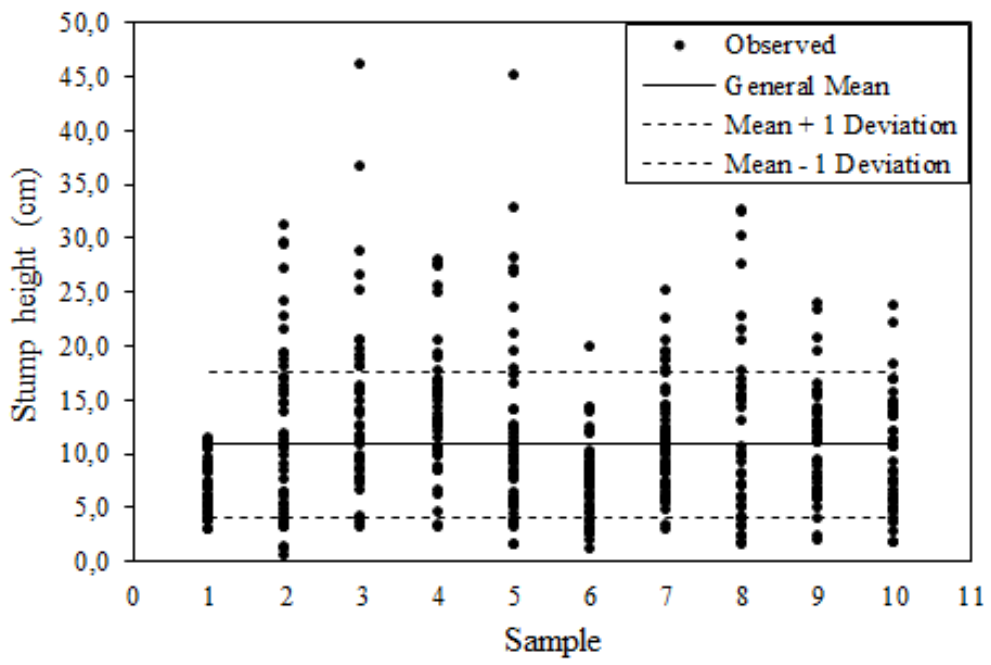

Fig. 1: Dispersion of stump height values by sample plot; Black line: general mean of all plots; Dashed lines: general mean plus or minus one value of standard deviation.
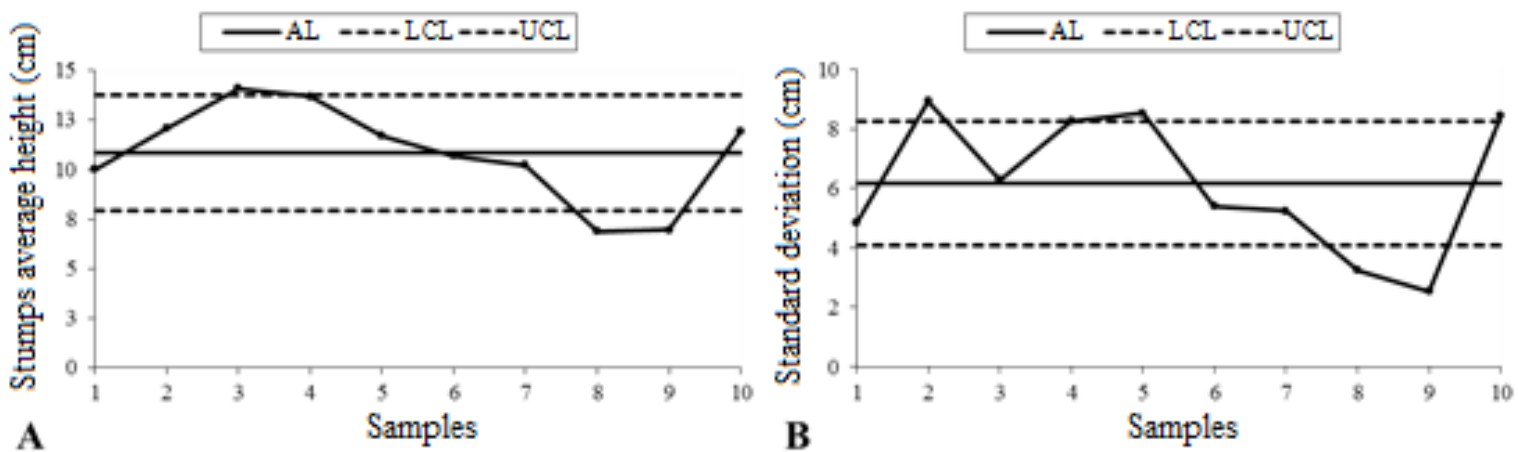

Fig. 2: Statistical process control charts for stump height, considering the mean (A) and standard deviation (B).

AL: mean line; LCL: lower limit of control; UCL: upper limit of control.

The points below the LIC are desirable as they infer that less wood was left on the field. However, regardless, the average height of stumps showed number above the limit specified by the company. 
In relative terms, $46.6 \%$ of the evaluated stumps were above the specified limit and, in general, the occurrence of stumps above the standard did not show any relation to the terrain slope (Figure 3A).

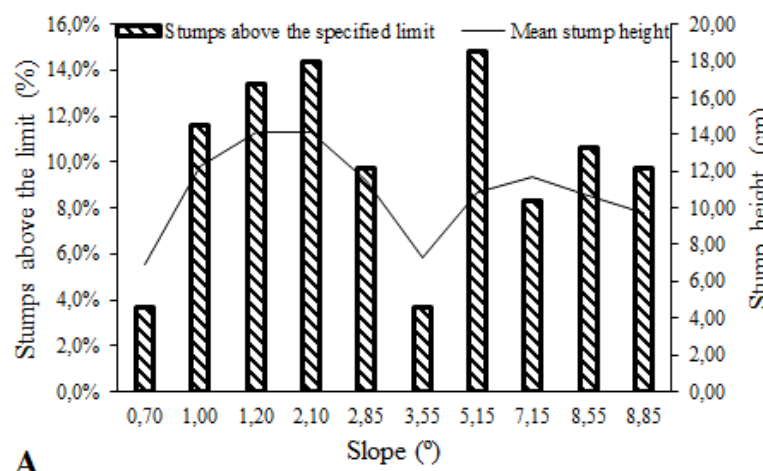

Fig. 3: Mean height and percentage of stumps above the specified limit as a function of terrain slope (A) and stump diameters classes (B).

Stumps above the standard occurred in greater proportion in the intermediate diameter classes (between 10 and $30 \mathrm{~cm}$ ) (Figure 3B). Meanwhile, the greatest values of theheights of the stumps were observed in either the lowest $(0-10 \mathrm{~cm})$ or the highest class $(>40 \mathrm{~cm})$, respectively.

The greatest heights of the stumps were observed in the lowest diameter class because tree belonging to this class were notfelling by the action of the cutting implement (Feller Buncher).Most of the times they were felling by adjacent larger trees that fell over them. However, in the highest class (over $40 \mathrm{~cm}$ ) the high stump heights observed may be associated with the operator's difficultieswhile performing the felling operation, which is also reported by Jacovine et al. (2005).

Similar results were reported by Martins (2017), which evaluated the activity of tree felling of pine stands by Feller Directional, and found a mean stump height of $10.86 \mathrm{~cm}$, result of a statistically unstable process according to the statistical control charts of the process.Another similar result is from Pereira et al. (2012) which analyzed the eucalyptus tree felling activity using chainsaws and found a mean stump height of $10.49 \mathrm{~cm}$, being therefore out of compliance with the desired pattern. According to the authors, the average value of wood loss in the assessed situation was $2.43 \mathrm{~m}^{3} \mathrm{ha}^{-1}$, which economically represented a loss of income of $55.21 \mathrm{US} \mathrm{ha}^{-1}$.

In the present study, wood losses, accounting stumps above the desired standard, averaged $1.06 \mathrm{~m}^{3} \mathrm{ha}^{-1}$

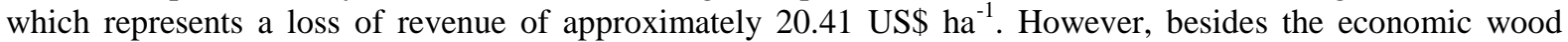
losses, stumps are physical impediments to the operations with soil preparation machines during the land reform for a next planting (Casselli, 2013), which results in operations of withdrawing or lowering stumps, burdening the reform costs and reducing the income of the forest production (Moro et al., 1988; Seixas and Mendo, 1990).

In this way, it was observed that in addition to the decrease in revenue from wood loss, there will be an indirect increase in silvicultural costs, which will also contribute to a decrease in the profitability of the plantations.Fact described byPereira et al. (2013), in areas with eucalyptus stumps with a mean height of 21.00

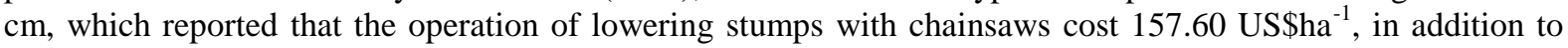
revenue losses due to wood waste.

Considering the accuracy of the precision on the bucking of the trees on the field, only $1.20 \%$ of the logs were outside the desired limit of conformity (Figure 4) and the process could be considered stable since the upper limit control was violated only by one mean (Figures $5 \mathrm{~A}$ and $5 \mathrm{~B}$ ). 


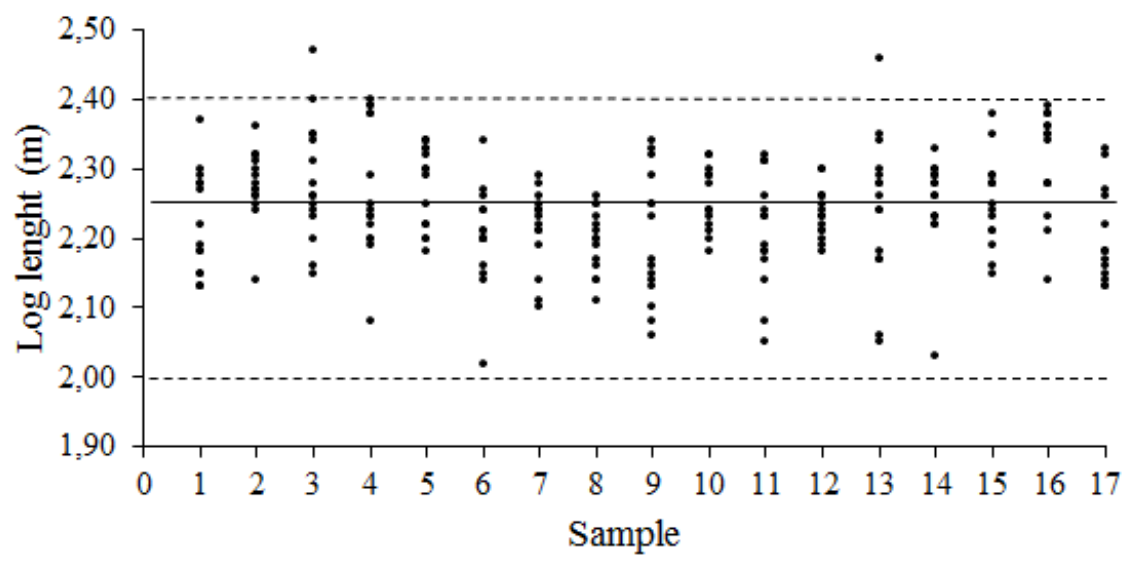

Fig. 4: Dispersion of log length values by sample plot. Continuous line: desired specification (2.20 m); Dashed lines: upper and lower specification limits.
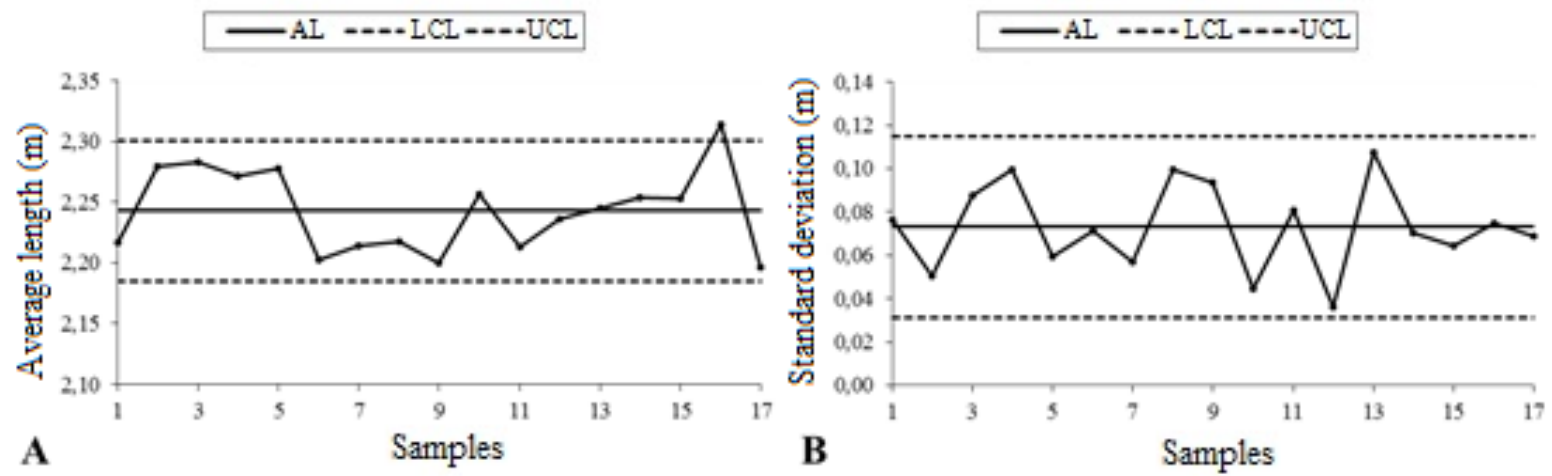

Fig. 5: Statistical process control charts for length of logs in the field, considering the mean (A) and standard deviation (B). AL: mean line; LCL: lower limit of control; UCL: upper limit of control.

Figure 6 shows the results for the log cutting at the company yard process where $10.3 \%$ of the sampled logs length were below the desired standard, $23.8 \%$ above and $65.9 \%$ in compliance.

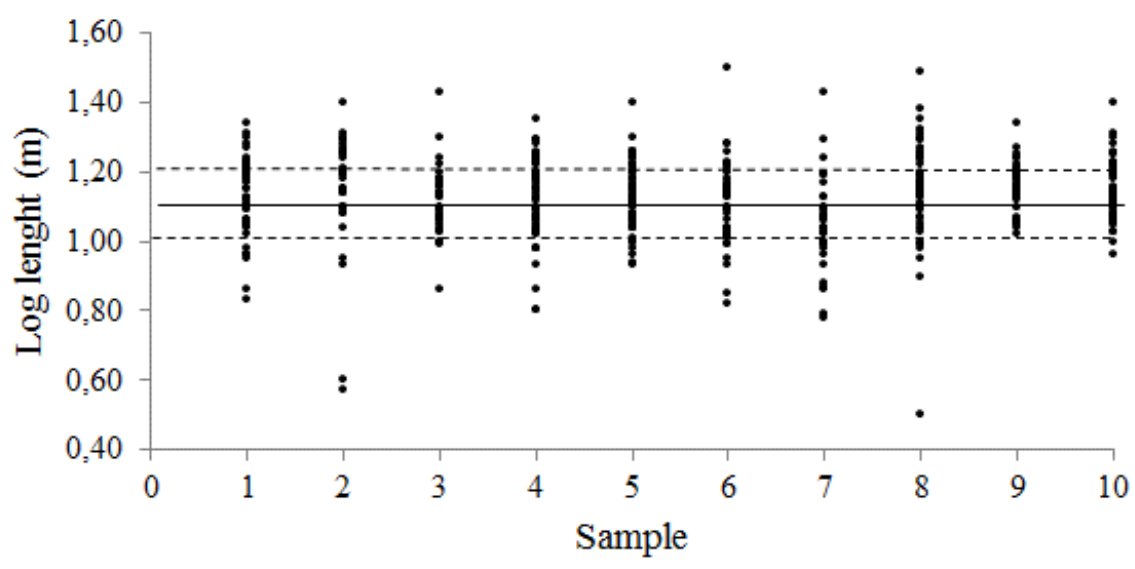

Fig. 6: Dispersion of log length values by sample plot. Continuous line: desired specification (1.10 m); Dashed lines: upper and lower specification limits.

The quality item above presented a higher variation in relation to the other items violating the LIC and LSC limits (Figure 7A and 7B). This violation demonstrates that the process is not under control and can be justified by the operational characteristics of the equipment used (Grapple Saw), which does not have a template to perform the operation and, therefore, resulting in length errors after log cutting. 

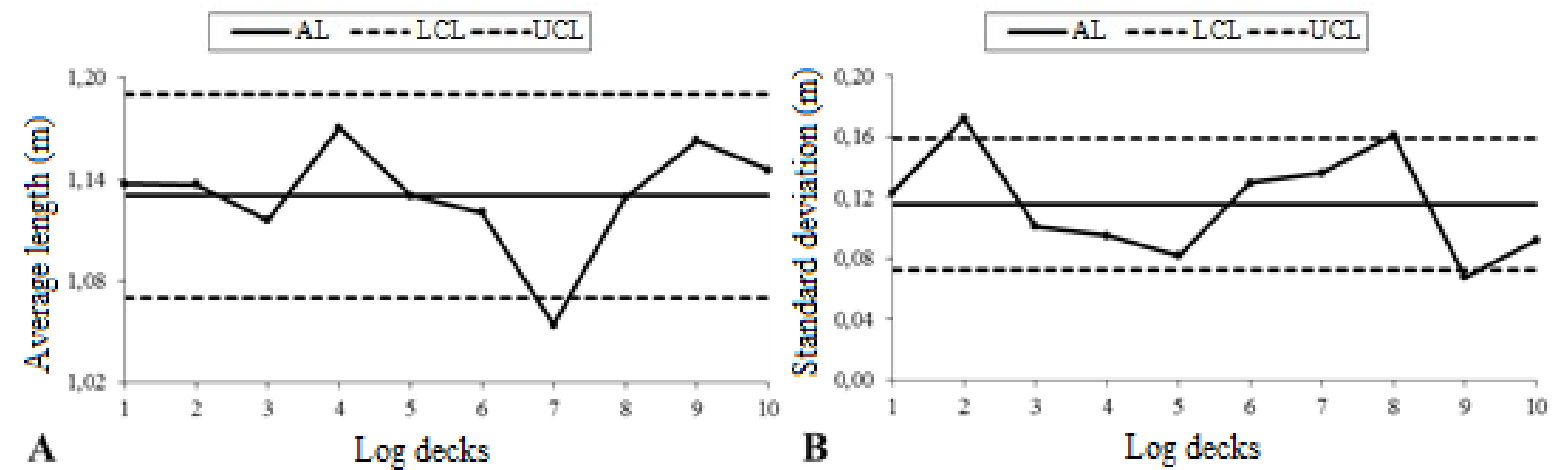

Fig. 7: Statistical process control charts for length of logs at company yard, considering the mean (A) and standard deviation (B). AL: mean line; LCL: lower limit of control; UCL: upper limit of control.

Rezende et al. (2000) analyzing the bucking of eucalyptus trees on the field process with chainsaw, observed that the process was unstable due mainly to the lack of training of the operators and recommended greater investment in the supervision and control procedures of the activity.Fiedler et al. (2013) also observed this fact and realized that, in addition to the losses of wood and revenue, the low quality of forest harvesting operations can trigger several problems in subsequent operations of raw material processing and use.

Overall, actions are necessary in order to improve the quality of operations, reduce possible wastes, improve logistics and reduce redoing costs of the wood industrial supply.

\section{Conclusions:}

Among the three items related to the quality of the forest harvesting process in clear-cut operations of eucalyptus stands for energetic purposes, only the tree bucking in the field showed compliance and, hence, being statistically controlled. Tree felling andlog cutting at the company yardhave not been compliant and are out of statistical control.

The quality of the eucalyptus tree felling activity, represented by the stump height, did not present a relation to the terrain slope, with the mean stump height being higher in classes with a diameter of 0 to $10 \mathrm{~cm}$ and greater than $40 \mathrm{~cm}$, which was caused due to lack of training and skill of the operator.

In addition to the economic loss of revenue from wood waste on non-compliant stumps, the low quality of tree felling activity reflects on higher stumps that cause subsequent problems in silvicultural operations, burdening implantation costs and reducing forest production revenue.

The quality of the tree bucking in the field, represented by the length of logs, presented only $1.20 \%$ of logs outside the desired limit of compliance, therefore, the process was stable and there was no need for measures to improve this process, although it is recommended that the process be evaluated and supervised.

The quality of the log cutting at the company yard activity presented high variation and dispersion of values in relation to the log length precision, due to the lack of process control. Nevertheless, the equipment used for the activity does not have any device to measure the quality of work, being the quality of the activity dependentof operator's ability.

The present work showed how important it is for adopting tools to improve quality management in forest operations, especially in the timber harvesting. When the initial forest operations processhavelow quality, they affect all subsequent operations and the losses are greater, given the chain effect.

In general, the Statistical Process Control tool was efficient in evaluating the timber harvesting process of the present situation, demonstrating the need for investment in supervision and training of personnel to avoid wood waste andfinancial losses in forest production. Still, it is also recommended to evaluate alternatives for using other forest harvesting equipment with the objective of improving the quality of operations and increasing the profitability of the production process.

Not all harvesting operations and all possible consequences of lack of conformity were evaluated in this study, but it is believed that most of the quality problems occurred during the harvesting operationswere from these items, and the others could be studied. Therefore, because of the high potential for economic losses, investment in quality can be rewarding. Thus, any investment in prevention and evaluation could increase the returns of forest enterprises.

It is also recommended that other situations, harvesting systems and production objectives be studied, as well as the costs and consequences of low quality in forest operations, since there is scarce work in the specialized scientific literature and will certainly support decision making in planning of forest operations. 


\section{ACKNOWLEDGEMENT}

To forestry company for granting access to their areas and for logistical support to carry out the study.

\section{REFERENCES}

Alvares, C.A., et al., 2013. Köppen's climate classification map for Brazil.MeteorologischeZeitschrift, Stuttgart, 22(6): 711-728.

Casselli, V., 2013.Remoção de tocos de eucalipto com sistema deserra tubular. São Paulo - Piracicaba, pp:111.

Epagri, 2017. Centro de informações de recursosambientais e de hidrometeorologia de Santa Catarina.Agroecological Zoning. Santa Catarina - Florianópolis.

Fiedler, N.C., F.C.A. Carmo, G.B. São Teago, A.A. Campos, E.N. Silva, 2000. Análise da qualidade da colheitaflorestal deeucaliptoemdiferentesdec lividades. Revista Científica Eletrônica de Engenharia Florestal, 22(1): 1-8.

Indústria Brasileira de Árvores, 2017. RelatórioAnual 2017. Distrito Federal - Brasília, pp: 80.

Jacovine, L.A.G., C.C. Machado, A.P. Souza, H.G. Leite, L.J. Minetti, 2005. Avaliação da qualidadeoperacionalemcincosubsistemas de colheitaflorestal. RevistaÁrvore, 29(3): 391-400.

Jacovine, L.A.G and C. Trindade, 2014. Qualidade total naatividade de colheitaflorestal: Colheitaflorestal. 3. ed. Viçosa:EditoraUFV, pp: 35.

Machado, C.C., E.N. Silva, R.S. Pereira, 2014. O setorflorestalbrasileiro ea colheitaflorestal: Colheitaflorestal. 3 ed. Viçosa: EditoraUFV, pp: 27.

Martins, B.M., 2017. Indicadorescríticos de qualidadeemoperaçõesmecanizadas de colheitaemdesbaste e corteraso de PinustaedaL.. Santa Catarina - Lages, pp: 92.

Montgomery, D.C., 2004. Introduçãoaocontroleestatístico daqualidade. Rio de Janeiro: LTC, pp:513.

Moro, L., J.L. Cominato Junior, G. Colli Junior, R.A. Caneva, 1988. Rebaixamento de tocos de eucaliptos. IPEF, 165: 1-3.

Oakland, J.S., 2003. Statistical Process Control. Oxford: Butterworth-Heinemann, pp: 445.

Pereira, P.P., N.C. Fiedler, P.P. Guimarães, R. Mora, H.M.R. Bolzan, O.B. Plaster, 2012. Avaliação da qualidade do corteflorestal com motosserra. RevistaCerne, 18(2): 197-203.

Pereira, R.S., R. Silvestre, M.E. Nappo, E.P. Miguel, F. Emmert, 2013. Qualidade da colheita e atributosfísicos do solo: implicações noplanejamento da reforma de povoamentos florestais. Revista Engenhariana Agricultura, 21(3): 223-233.

Rezende, J.L.P., L.A.G. Jacovine, H.G. Leite, C. Trindade, 2000. Avaliação da qualidadenacolheitaflorestalsemimecanizada. Scientia Forestalis, 57: 3-26.

Seixas, F. and L.J.L. Mendo, 1990. Teste de implemento para rebaixamento de tocosemraízes de reforma de reforma de povoamento de eucalipto. Circular Técnica, IPEF, 173: 1-6.

Siqueira, J.D.P., R.S. Lisboa, A.M. Ferreira, M.F.R. Souza, E. Araújo, L.L. Júnior, M.M. Siqueira, 2004. Estudoambientalpara osprogramas de fomentoflorestal daAracruzCelulose S.A. e extensãoflorestaldo Governo do Estado do Espírito Santo.RevistaFloresta, 11: 3-67.

Trindade, C. et al., 2007. Ferramentas da qualidade: aplicaçãonaatividadeflorestal. Viçosa: Editora UFV, pp: 158 .

Trindade, C. et al., 2012. Gestão e controle da qualidadenaatividadeflorestal. Viçosa:Editora UFV, pp: 253. 